\title{
Safety Issues, Security and Risk Management in Nautical Tourism
}

\author{
Josip Kasuma, Jelena Žanić Mikuličićb, Vinka Kolićc
}

The relatively new nautical market gave rise to a special kind of tourism. Nautical tourism as a system has the characteristics of a traffic system with all its peculiarities. Nautical tourism is steadily increasing. In countries nurturing this type of economic activity, nautical tourism has the characteristics of mass tourism. Nautical tourism is a complex system consisting of and using various forms of technical and technological processes. As such it is exposed to various risks. Therefore, this paper proposes a systematic approach to the development of safety measures in nautical tourism.

\section{KEY WORDS}

$\sim$ Security

$\sim$ Safety

$\sim$ Risk management

$\sim$ Nautical tourism a. University of Split, University department of forensic sciences, Split, Croatia e-mail: josip.kasum@unist.hr

b. University of Split, Faculty of maritime studies, Split, Croatia

e-mail: jzanic@pfst.hr

c. Hydrograhic Institute of the Republic of Croatia

e-mail: vinka.kolic@hhi.hr

doi: 10.7225/toms.v07.n02.008

This work is licensed under (cc) BY

\section{NAUTICAL TOURISM}

Nautical tourism is a special kind of tourism. Nautical tourists navigate through various aquatic environments - seas, rivers and lakes. According to this division, nautical tourism has the special characteristics of nautical tourism on the coast, on rivers and lakes. Tourism at sea is more hazardous than nautical tourism on rivers and lakes. However, nautical tourism on rivers and lakes in Europe and other parts of the world is increasingly gaining importance. Nautical tourism is a process consisting of functional elements equivalent to the processes in other types of transport,

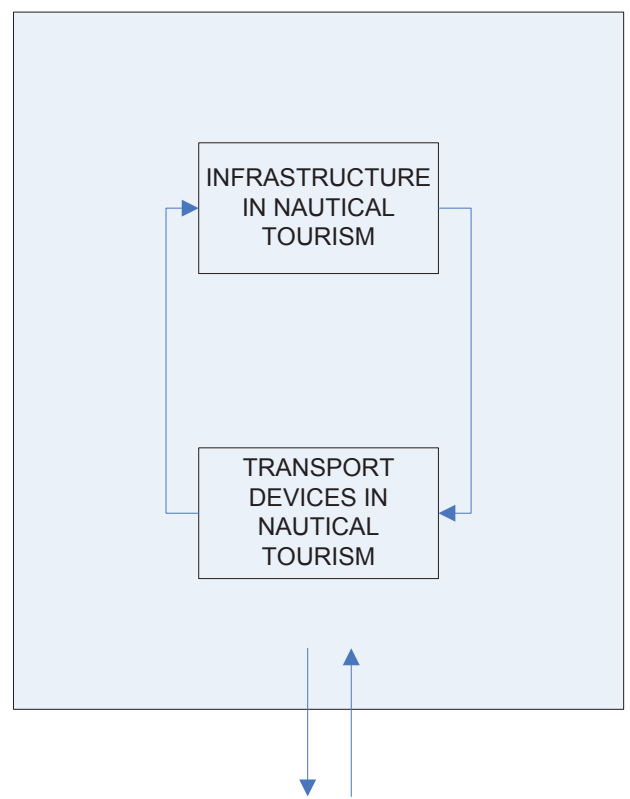

ENVIRONMENT

Figure 1.

Systematic model of nautical tourism. 
such as maritime transport or transport along inland waterways, rivers and lakes. Therefore, nautical tourism can be considered a type of transport process with specific characteristics. If seen as a traffic process, it could be systematically defined with a model (Figure 1).

Nautical tourism as a transport system consists of the infrastructure and transport equipment subsystems (EPCI, 2018; Stipanović, Gračan and Bradetić, 2012). Thus, the infrastructure subsystem is a technical-technological land-based system in the function of the nautical market, e.g. various types of marinas with their surroundings. In Italian, the term marine means a relatively small arc essential to the acceptance and/or stay of vessels in nautical tourism. According to "The National Association of Engine and Boat Manufactures Incorporated of America" - USA, a marina is a facility suitable for vessel anchoring, launching, repair and supply. It also offers showering and catering amenities nearby commercial, communication and transport infrastructure. Marina as a subsystem in the nautical market is used for the receipt and stay of vessels in nautical tourism, including tourists - boaters at sea, rivers and lakes. A marina can either be an independent facility with own infrastructure or a part of a larger port for other purposes.

According to the type of construction and level of equipment, marinas are divided into EU and USA types. USA marinas are recognizable by their relatively low-cost, standardized and quality construction. Infrastructural facilities of such marinas are extremely functional and versatile. USA marinas are characterized by efficient business organization. Their construction differs from that of EU marinas which have a relatively poor internal infrastructure and smaller capacity. In practice, we have the concept of dry dock marinas, i.e. landbased facilities rendering services and / or serving as vessel storages in nautical tourism. Depending on their position $(\lambda$ and $\rho)$ and the waterway on which they are situated, in different countries marinas can be classified as lake, inland waterway and sea marinas. Thus, for example, lake marinas can be considered relatively calm and safe in terms of weather conditions. Sailing boat area in lake marinas is certainly limited by the size of the lake and possible connections with other waterways, other inland areas or the lack thereof, and the sailing characteristics of vessels in nautical tourism. In rivers, the size of the marina depends on the size of the river. Therefore, the navigation area of vessels in nautical tourism is limited by the river's buoyancy and sailing characteristics of vessels in nautical tourism. Sea marinas are considered to be the most widespread type. Judging by the vessels received, they cater to the largest vessels. Vessel navigation area is limited solely by the characteristics of vessels in nautical tourism. An overview of marina plans, available in various marine navigation publications, clearly shows that some are designed to follow the natural characteristics of the land, while others are freely designed or combine these two approaches. Nautical tourism can also have a substantial environmental impact. Certain processes in the ports of nautical tourism increase the impact of various forms of environmental pollution. So, the environmental impact of nautical tourism can be divided into three stages: construction, use and end of use (Kasum, Vidan and Baljak, 2010). Vessels in nautical tourism have impact on the environment during their stay in ports of nautical tourism and sailing. The subsystem of nautical tourism transport devices includes all technical-technological water and/or sea systems in the function of nautical market (Stipanović, Gračan and Bradetić, 2012). Generally, under the Convention on the Safety of Life at Sea (Safety of Life at Sea, SOLAS), vessels are divided into convention and non-convention vessels (SOLAS, 2009). Convention vessels are vessels bigger than $500 \mathrm{GT}$, including cruise ships. Non-convention vessels are military and police boats, government ships, warships, fishing vessels and boats of primitive construction, as well as pleasure crafts i.e. vessels in nautical tourism. The transport device subsystem of the nautical market pertains to non-convention vessels i.e. pleasure boats: yachts, sailboats, power boats, rafts and other boats. As for the financial impact of nautical tourism in countries with this type of economic activity, it can be argued that it is relatively more profitable than other forms of tourism. However, as a special form of tourism with transport system characteristics, it requires a special approach, particularly in terms of safety, security and risk management, as seen in the general model (Figure 2).

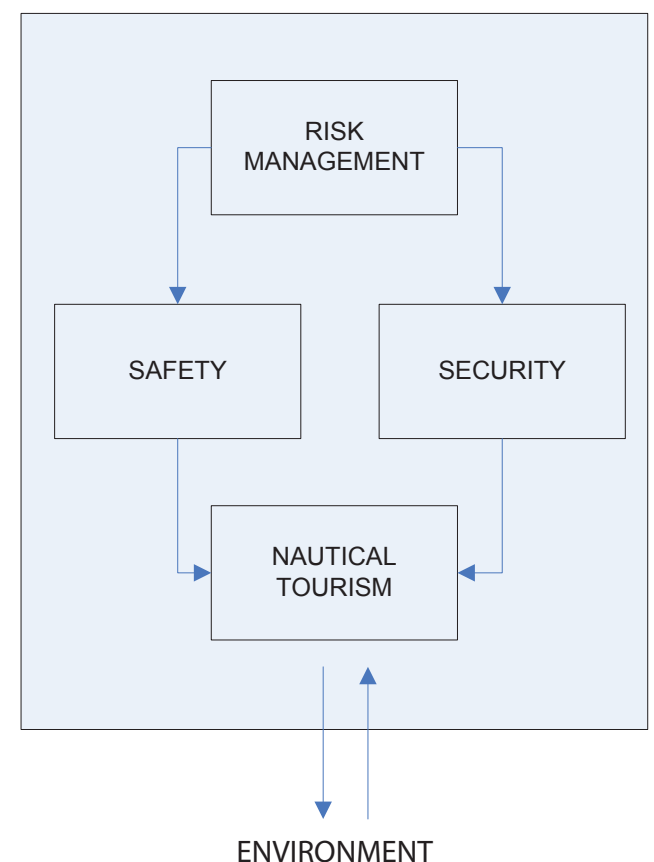

Figure 2.

The general model of safety issues in nautical tourism. 
In conclusion, nautical tourism can be systematically described as an organized entity with infrastructure and transport equipment subsystems designed to meet the special needs of tourists - boaters.

\section{SAFETY OF NAVIGATION IN NAUTICAL TOURISM}

The safety of navigation in nautical tourism includes all measures of state and other authorities intended to ensure safe navigation (Kasum et al., 2006-A). The measures include legal regulations, the development and use of technical, technological and other resources. In addition to these factors, the safety of navigation also has a direct impact on the accuracy of auxiliary means such as the information content of charts and nautical publications. The safety of navigation depends on the level of knowledge and skills of boaters - tourists in nautical tourism. Their level of knowledge differs depending on the place of education. Therefore, a certain standard of education of persons involved in the operation of the infrastructure and transport means subsystems in nautical tourism should always be maintained. The Republic of Croatia is an example of good practice, with developed nautical tourism activities. Owing to the increasing activity in nautical tourism, marine and yacht technology instructions and maritime management have been

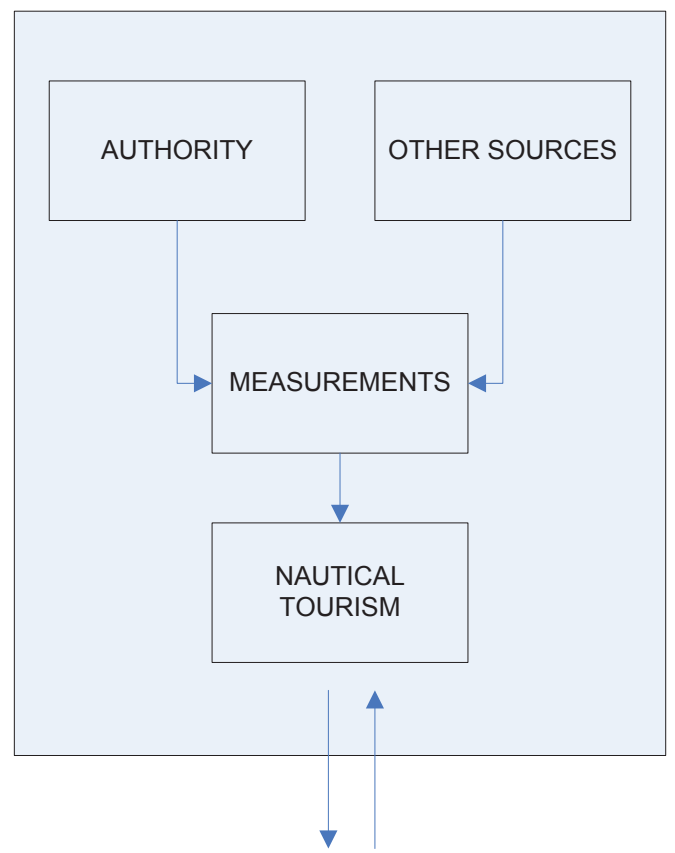

ENVIRONMENT

Figure 3

General model of safety of navigation in nautical tourism. implemented into the programs of the Maritime University of Split, Croatia. These programs explore the contents closely associated with the activities of the boating market. They provide students with knowledge and competence, and nautical tourism companies with quality human resources.

The significant increase in the safety of navigation in nautical tourism can be concluded to affect the development and implementation of measures in these areas such as legal and other things.

\section{SECURITY IN NAUTICAL TOURISM}

To protect and ensure the safety of Convention ships navigating the world's seas, rivers and lakes, a system of rules called the ISPS Code (International Standards for Port Safety and Security Code) was developed (ISPS and SOLAS, 2003). Nonconvention vessels, including ships and boats in nautical tourism also navigate the world's seas, rivers and lakes and use marinas of nautical tourism. By function and activity, nautical tourism activities are clearly identical to the activities of Convention ships, but are not provided with equivalent security. Croatia can serve as an example of the growing number of vessels in nautical tourism, with the number of vessels in nautical tourism increasing from 160,000 to 250,000 in 2011 (ISPS and SOLAS, 2003) in only five years. Assuming a minimum of four tourists - boaters on each vessel, the Croatian Adriatic coast can be surmised to have been visited by approximately 1,000,000 people in the summer of 2011.

The lack of rules regulating the security of this category of vessels and ports can be concluded to represent a real risk to the safety of vessels in nautical tourism, nautical tourism and people.

\section{RISK MANAGEMENT IN NAUTICAL TOURISM}

Risk, i.e. predicted or expected damage arising from any variety of hazards, losses, threats, etc. is calculated. Management as a concept can be kept as an organized monitoring method. Nautical tourism is exposed to various forms of danger, losses, threats, human trafficking etc. which can be determined along with the concept of risk in nautical tourism. Therefore, risk management in nautical tourism can be defined as a process aiming to monitor processes in nautical tourism and in the infrastructure and transport equipment subsystems, i.e. on vessels in nautical tourism. Generally speaking, the level of risk is equal to the probability function and the potential risk of adverse events. In nautical tourism, perceived as a specific transport process, risk occurs in the infrastructure and transport means subsystems. A process with measurable parameters can be conducted. Therefore, parameters essential for conducting the risk management process in nautical tourism should be defined (Figure 4). 


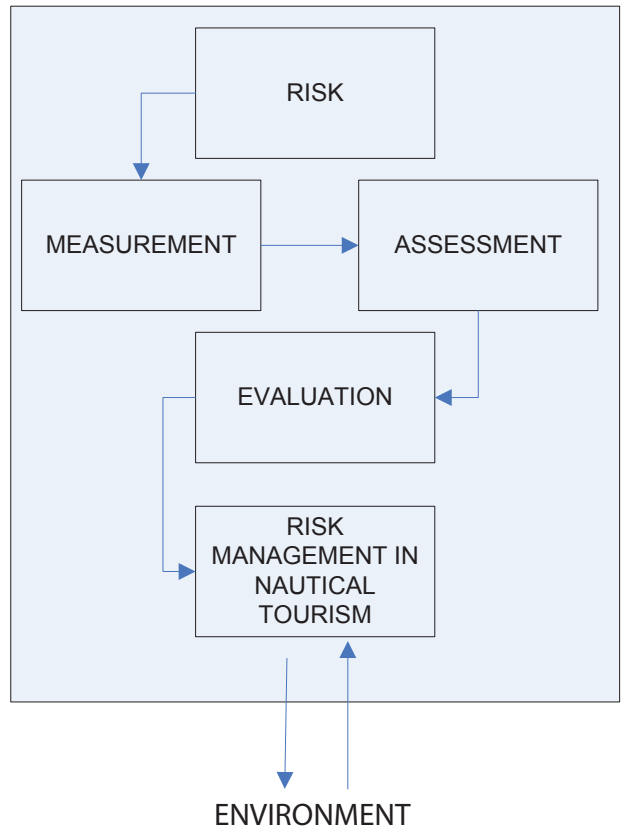

Figure 4.

The model of risk management in nautical tourism.

Table 1.

Elements of risk management in nautical tourism.

\begin{tabular}{lll}
$\begin{array}{l}\text { SOME ELEMENTS OF } \\
\text { RISK IN NAUTICAL } \\
\text { TOURISM }\end{array}$ & REMARK & $\begin{array}{l}\text { MEASUREMENT } \\
\text { RESULTS }\end{array}$ \\
\hline Infrastructure & $\mathrm{R}_{1}$ & MARK \\
\hline Yacht & $\mathrm{R}_{2}$ & $\mathrm{n}$ \\
\hline Sailboat & $\mathrm{R}_{3}$ & $\mathrm{n}$ \\
\hline Speedboat & $\mathrm{R}_{4}$ & $\mathrm{n}$ \\
\hline Boat & $\mathrm{R}_{5}$ & $\mathrm{n}$ \\
\hline Raft & $\mathrm{R}_{6}$ & $\mathrm{n}$ \\
\hline Other vessels & $\mathrm{R}_{7}$ & $\mathrm{n}$ \\
\hline Security & $\mathrm{R}_{8}$ & $\mathrm{MARK}$ \\
\hline No. of tourists-boaters & $\mathrm{R}_{9}$ & $\mathrm{n}$ \\
\hline by $\mathrm{M}^{2}$ & & $\mathrm{n}$ \\
\hline Vessel density by $\mathrm{M}^{2}$ & $\mathrm{R}_{10}$ & $\mathrm{t}$ \\
\hline Season & $\mathrm{R}_{11}$ & $\mathrm{v}$ \\
\hline Forecast & $\mathrm{R}_{12}$ & $\mathrm{x}, \mathrm{y}, \mathrm{z}$ \\
\hline Position & $\mathrm{R}_{13}$ & $\mathrm{MARK}$ \\
\hline Environmental impact & $\mathrm{R}_{14}$ & $\mathrm{~nm}$ \\
\hline Other & $\mathrm{R}_{\mathrm{n}}$ & \\
\hline & & \\
\hline
\end{tabular}

Table 1 is an overview of certain risk elements in nautical tourism which should be properly monitored.

The conclusion is that extant nautical tourism risk management measures, such as: strategic marina management (Kasum, Bozic-Fredotovic and Vidan, 2009), security (Kasum, Vidan and Baljak, 2006), navigation safety (Kasum et al. 2006-B; Kasum, Baljak and Vidan, 2007; Kasum, Gržetić and Marušić, 2007; Kasum, Vidan and Skračić, 2010), the security of the environment in nautical tourism (Kasum, Vidan and Baljak, 2010), e-navigation (IHO, 2018), critical infrastructures (EPCIP, 2018) should be applied and new measures developed (Kasum, Vidan and Baljak, 2006). It is important to sensitize the global community about the problems and potential risks in nautical tourism, develop and implement an appropriate standardized risk management model in nautical tourism on a global level.

\section{CONCLUSION}

The relatively new nautical market can be considered to be a meeting point of supply and demand of goods and services in nautical tourism. In the framework of the systematic analysis of this transport system type, the infrastructure and transport equipment subsystems have been observed. The infrastructure subsystem of the nautical market includes technicaltechnological systems, water and/or the sea in the function of the nautical market. The term transport subsystem of the nautical market refers to all technical-technological systems which can be used in navigation in nautical tourism. Nautical tourism is systematically organized as a whole intended to meet the special needs of tourists - boaters. Nautical tourism as a system is exposed to various risks. To improve risk management in nautical tourism, legal and other measures regulating the safety of navigation need to be developed and implemented. To ensure better protection, the development of rules regulating the safety of this category of vessels and ports should be supported.

The harmonized development and implementation of risk management systems in nautical tourism at the international level can reasonably be expected to significantly reduce risk.

\section{REFERENCES}

E-Navigation, 2018. Wikipedia Article. Available at: http://en.wikipedia.org/wiki/ENavigation

European Programme for Critical Infrastructure Protection, 2018. EU Center. Available at: http://www.eucenter.org/index.php?action=programs\&process=deta il\&id=99

International Hydrographic Organization, 2018. Webpage. Available at: http://www. iho.int/srv1/, accessed on: May 17th 2018.

International Maritime Organization, 2018. Webpage. Available at: http://www.imo. org/, accessed on: May 17th 2018. 
ISPS Code and SOLAS Amendments, 2003. Available at: http://www.ubak.gov.tr/ BLSM_WIYS/DISGM/tr/HTML/20130304_142647_66968_1_67502.pdf, accessed on: September 2nd 2018

Kasum, J., 2011. Maritime affairs, safety of navigation and security. NMIOTC MIO Journal, NATO Maritime Interdiction Operational Training Center, 4.

Kasum, J., Baljak, K. and Vidan, P., 2007. Evaluation of the existing piracy protective measures, ISEP 2007 Conference Proceedings, Ljubljana, Slovenija, pp. M5.

Kasum, J., Baljak, K. and Vidan, P., 2008. Threats to ships and ports of inland navigation. International Conference on Ports and Waterways. POWA 2008, Croatia.

Kasum, J., Bozic-Fredotovic, K. and Vidan, P., 2009. How nautical tourism ports affect the environment. Management of Natural Resources, Sustainable Development and Ecological Hazards II. Available at:

http://dx.doi.org/10.2495/rav090111.

Kasum, J., Gržetić, Z. and Marušić E., 2007. Contribution to the development of management and strategic decision making in nautical tourism ports. Promet Traffic \& Transportation, 19.

Kasum, J., Marušić, E. and Gržetić, Z., 2006-A. Contribution to the Development of the Model of Managing Reambulation in Ports. Promet - Traffic \& Transportation, $18(3)$, pp. 223-228

Kasum, J., Marušić, E. and Gržetić, Z., 2006-B. Security of non-convention ships and nautical tourism ports. TIEMS Conference, Seoul.
Kasum, J., Vidan, P. and Baljak, K., 2006. Act about safety protection of merchant ships and ports open to international traffic and its implementation. ICTS 2006 conference proceedings. Portotož, Slovenija.

Kasum, J., Vidan, P. and Baljak, K., 2010. Threats and New Protection Measures in Inland Navigation. PROMET - Traffic\&Transportation, 22(2). Available at: http://dx.doi.org/10.7307/ptt.v22i2.173.

Kasum, J., Vidan, P. and Skračić, T., 2010. Maritime radiation protection and seaman's safety. ISEP 2010 Proceedings, Ljubljana, Slovenija.

Lipowicz, A., 2005. EU to Spend Far Less for Infrastructure Protection. Washington Technology. Available at: https://washingtontechnology.com/articles/2005/07/05/ eu-to-spend-far-less-for-infrastructure-protection.aspx.

Ministry of the Sea, Transport and Infrastructure, 2018. Webpage. Available at: http://www.mmpi.hr

Romanian President Urges EU to Establish Intelligence Community, 2006. People's Magazine. Available at: http://english.people.com.cn/200610/19/ eng20061019_313299.html.

SOLAS Convention, 2009. Available at: http://www.mar.ist.utl.pt/mventura/ProjectoNavios-I/IMO-Conventions\%20(copies)/SOLAS.pdf, accessed on: September 10th 2018.

Stipanović, C., Gračan, D. and Bradetić, M., 2012. The Development Concept in Function of the Competitiveness of marina Frapa Rogoznica. Naše More 59(1-2), pp. 61-69. 